Agricultural Journal 14 (5): 75-78, 2019

ISSN: 1816-9155

(C) Medwell Journals, 2019

\title{
Determing Extent in Changes of Vegetative Land Use/Land Cover using GIS and Remote Sensing Techniques in Obio/Akpor; Rivers State Nigeria
}

\author{
E.A. Igbanibo and C.C Wokocha \\ Department of Crop and Soil Science, Faculty of Agriculture, University of Port Harcourt, \\ Harcourt, Nigerias
}

\begin{abstract}
ArcGis 10.1 Software and Landsat 7 imageries of 1985 and 2017 were used for this study. The result of the research showed a rapid growth in built-up land occupying $182.2 \mathrm{~km}^{2}(70.0 \%)$ and cultivation occupying $7.4 \mathrm{~km}^{2}$ (2.9\%) in 2017 while 1985 witnessed a reduction in this classes having $83.4 \mathrm{~km}^{2}(32.0 \%)$ and $3.7 \mathrm{~km}^{2}$ (1.4\%), respectively. In 1985, vegetation occupied $169.9 \mathrm{~km}^{2}(65.3 \%)$ and experienced a reduction in 2017 to $67.4 \mathrm{~km}^{2}$ (25.9\%) while water body remained $3.3 \mathrm{~km}^{2}(1.3 \%)$ with little or no notable changes between the referenced years. It was also observed that the changes that occurred in the sampling points at the referenced years replicated itself in other parts of the study area, hence, the recommendation to raise awareness among relevant stakeholders about the importance of protecting vegetative land cover as well as the adverse effects and consequences associated with deforestation, overgrazing and improper agriculture activities on vegetation.
\end{abstract}

Key words: Vegetation, remote sensing, GIS, land use, land cover

\section{INTRODUCTION}

Vegetation is a key component of an ecosystem. It converts solar energy into biomass and forms the base of all food chains and influences the energy balance at the Earth's surface and within the atmospheric boundary layer, often mitigating extremes of local climate; it releases oxygen and sequesters carbon (Ayad, 2005). Vegetation affects soil development over time, generally, contributing to a more productive soil; provides wildlife habitat and food. It provides direct (e.g., timber) and indirect (e.g., watershed protection) socioeconomic products and services for humans. Vegetation can be easily described and mapped and therefore, can be used to monitor changes in cover, composition and structure due to natural or human-influenced events (Ejemeyovwi, 2015) (Fig. 1).

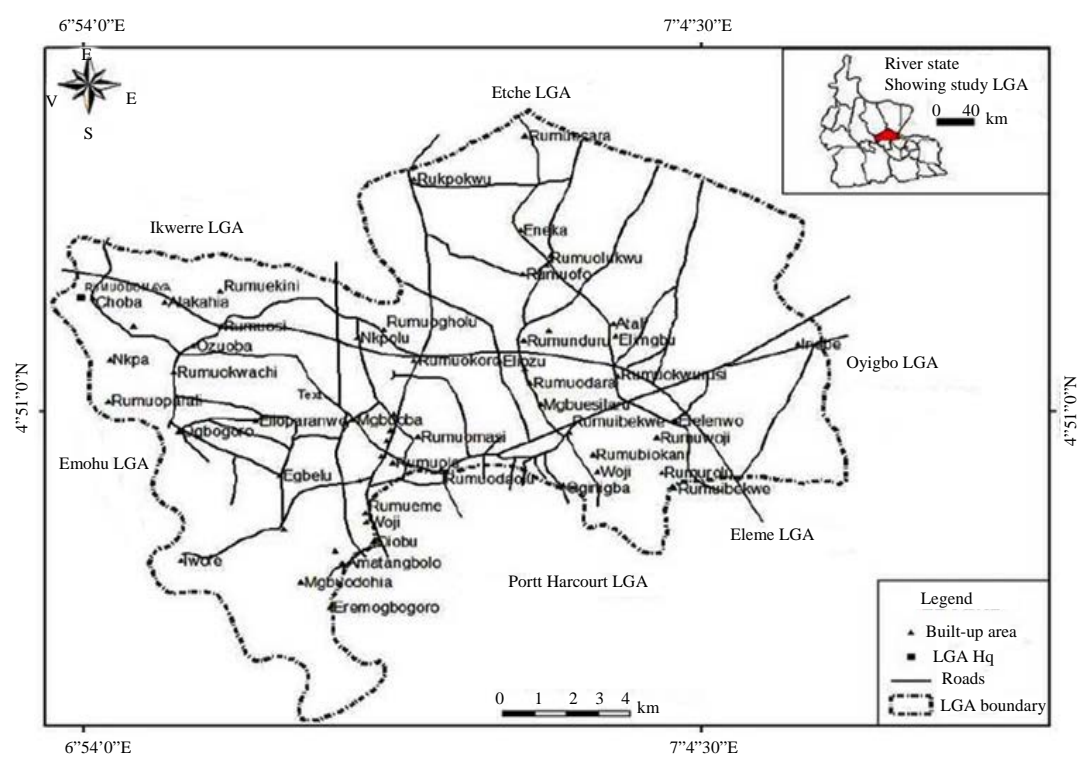

Fig. 1: Map of Obio/Akpor LGA showing its communities Arokoyu et al.

Corresponding Author: E.A. Igbanibo, Department of Crop and Soil Science, Faculty of Agriculture, University of Port Harcourt, Harcourt, Nigerias 
Land Use and Land Cover (LULC) changes detection is very essential for better understanding of landscape dynamic during a known period of time having sustainable management (Adeniyi and Omojala, 1999). It is a wide spread and accelerating process, mainly driven by natural phenomena and anthropogenic activities which in turn drive change that would impact natural ecosystem (Ruiz-Luna and Berlanga-Robles, 2003; Turner and Ruscher, 1988).

\section{Study area}

The study area: The study area, Obio/Akpor is a local government area which makes up part of the Port Harcourt metropolis, Rivers state. It is one of the major centres of economic activities in Nigeria and a major city in the Niger Delta area of Nigeria.

It is bounded by Port Harcourt LGA to the South, Oyigbo and Eleme to the East, Ikwerre and Etche to the North and Emohua to the West. It lies between latitudes $4^{\circ} 45^{\prime} \mathrm{N}$ and $4^{\circ} 60^{\prime} \mathrm{N}$ and longitudes $6^{\circ} 50^{\prime} \mathrm{E}$ and $8^{\circ} 00^{\prime} \mathrm{E}$ (Fig. 1).

\section{MATERIALS AND METHODS}

Primary source: The primary source of data was from direct field observation reconnaissance survey to get a general idea of the area features. Ground truthing was undertaken to confirm the features on the map and satellite images actually existed on ground. Pre-processing activities such as image restoration were performed on the images to enhance the readability of the features on satellites images.

Secondary source: The secondary data was sourced from journals, textbooks, articles, magazines, gazette and other publications. Satellite images of Choba were also used in the course of study.

Land use change analysis: The images which represent specific periods were used to study land use changes within the study area. Geographical Information System (GIS) was used to perform analysis on the acquired satellite images to determine the changes in land use and percentage change in the total areas covered for the study. Landsat 7 thematic imageries of 1985 and 2017.

Software used for remote sensing analysis: Software used was Arc GIS 10.1. This was used to display, process and enhance the image used. It was also used for carving out Obio/Akpor LGA and subsequently the sampling points from the satellite images of Rivers state.

\section{RESULTS AND DISCUSSION}

Change detection: The study was conducted for the years between 1985-2017 using remote sensing and GIS techniques which are very efficient in detecting the nature and location of changes as employed by the researcher. The land area was measured against each landuse and landcover type thus, identifying the magnitude of change (Table 1).

According to Table 2 built-up was $83.4 \mathrm{~km}^{2}$ (32.0\%) in 1985 because most people abandoned their farms and lands to seek for white collar jobs. It increased to $182.2 \mathrm{~km}^{2}(70.0 \%)$ in 2017 . This was due to an increase in urbanization, industrialization, oil exploration resulting from an increment in the population of the study area which therefore, lead to an increase in diseases, robbery, pollution as well as depletion and destruction of resources, land and food.

Cultivation was $3.7 \mathrm{~km}^{2}$ (1.4\%) in 1985 and increased to $7.4 \mathrm{~km}^{2}$ (2.9\%) in 2017 due to the increase in agricultural practices for both commercial farming as well as subsistent farming. People went back to the earlier abandoned farming (mostly crops) due to the government's ban on importation of food. Most agricultural products earlier imported were then grown locally. There was hence, a boost in agricultural activities in the study area, hence, the increase.

In 1985 vegetation was $169.9 \mathrm{~km}^{2}$ (65.3\%). There was a reduction in 2017 to $67.4 \mathrm{~km}^{2}(25.9 \%)$. This simply was due to an increase in rate of urbanisation, industrialisation as well as commercial activities. Many industries sprung up (banks, oil and gas servicing industries, gas stations and many more). These industries and companies occupied space and land that was earlier

Table 1: Landuse and landcover classification

\begin{tabular}{ll}
\hline Classes & Distribution \\
\hline Built up & Residential, commercial and industrial areas \\
Cultivation & Land used for growing crops \\
Vegetation & Ornamental trees, orchards, lawns and shrubs \\
Water body & Lakes, rivers, permanent open water, ponds, reservoirs \\
\hline Researcher's classification (2019)
\end{tabular}
Researcher’s classification (2019)

Table 2: Landuse and landcover change between 1985 and 2017

\begin{tabular}{|c|c|c|c|c|c|}
\hline \multirow[b]{2}{*}{ Classes } & \multicolumn{2}{|l|}{1985} & \multicolumn{3}{|l|}{2017} \\
\hline & $\begin{array}{l}\text { Area } \\
\left(\mathrm{km}^{2}\right)\end{array}$ & $\begin{array}{l}\text { Area } \\
(\%)\end{array}$ & $\begin{array}{l}\text { Area } \\
\left(\mathrm{km}^{2}\right)\end{array}$ & $\begin{array}{l}\text { Area } \\
(\%)\end{array}$ & $\begin{array}{c}\text { Magnitude } \\
\text { of change } \\
(\%)\end{array}$ \\
\hline Built up & 83.4 & 32.0 & 182.2 & 70.0 & 38 \\
\hline $\begin{array}{l}\text { Cultivation } \\
\text { (farmlands) }\end{array}$ & 3.7 & 1.4 & 7.4 & 2.9 & 1.5 \\
\hline Vegetation & 169.9 & 65.3 & 67.4 & 25.9 & -39.4 \\
\hline Water body & 3.3 & 1.3 & 3.3 & 1.3 & 0 \\
\hline Total & 260.3 & 100 & 260.3 & 100 & - \\
\hline
\end{tabular}

Researcher’s computation (2019) 
covered by vegetation. In essence the vegetal cover of the study area was reduced due to deforestation to make space for the springing up and construction of these companies.

Water bodies covers the total area of $3.3 \mathrm{~km}^{2}(1.3 \%)$, there was no notable change between 1985 and 2017 in the study area because water bodies in the study area were not affected by flooding which would have led to an increase in the water volume and consequently area covered by water bodies. Neither was it affected by sand-filling in the cause of urbanization in the study area.

This notable changes was replicated in all parts of the LGA in 1985 built up areas had a decline while in 2017 there was an increase in built up areas. Figure 2 and 3 shows a graphical illustration of the landuse rate between 1985 and 2017.

Magnitude of change: The graphical illustration (Fig. 4) shows that there were notable changes amongst land use

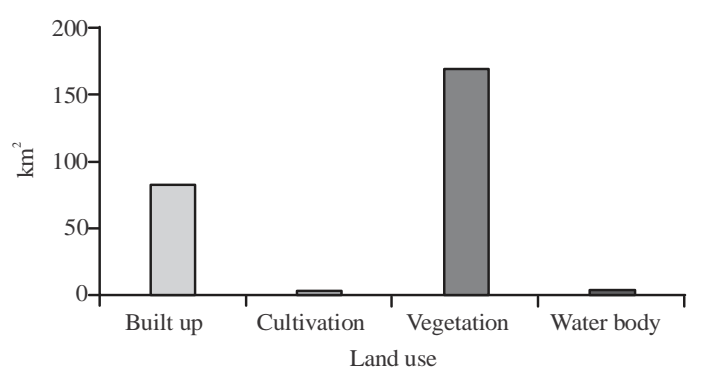

Fig. 2: Chart showing the landuse of $1985\left(\mathrm{~km}^{2}\right)$ type between 1985 and 2017. In 1985, there was not much of built up and cultivation land use types in the study area. Also, there was noticeable stability in the vegetation land use type simply because much urbanisation and industrialisation had hardly taken place in the study area (Fig. 6). In 2017, a huge increase in built up occurred due to urbanization an increase in cultivation as well due to the continuous agricultural practices where people resulted to subsistent farming during the ban on

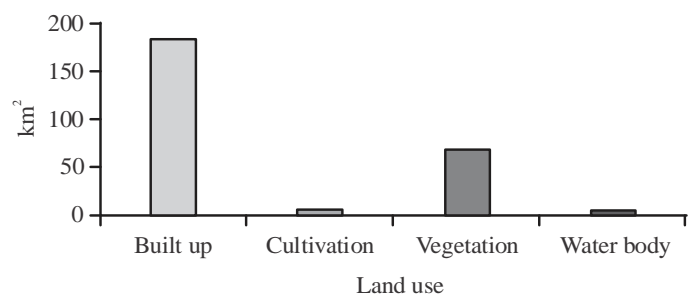

Fig. 3: Chart showing the landuse of $2017\left(\mathrm{~km}^{2}\right)$

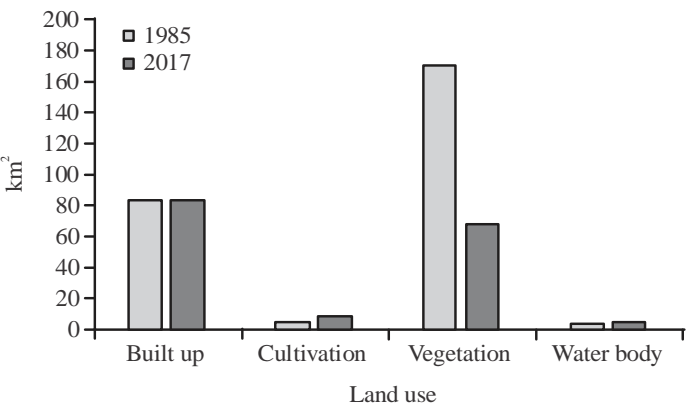

Fig. 4: Magnitude of change between 1985 and 2017

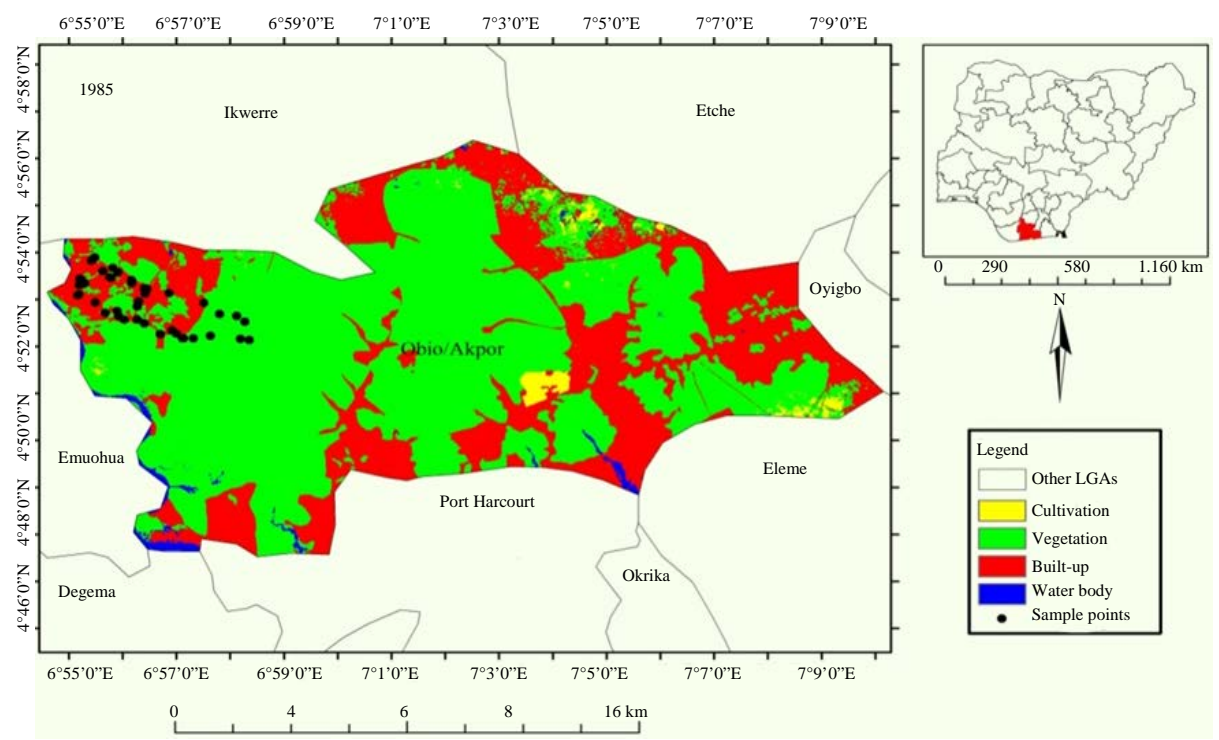

Fig. 5: Map showing the land use in the study area in 1985 (Department of Geography and Environmental Management, University of Port Harcourt. Choba) 
Agric. J., 14 (5): 75-78, 2019

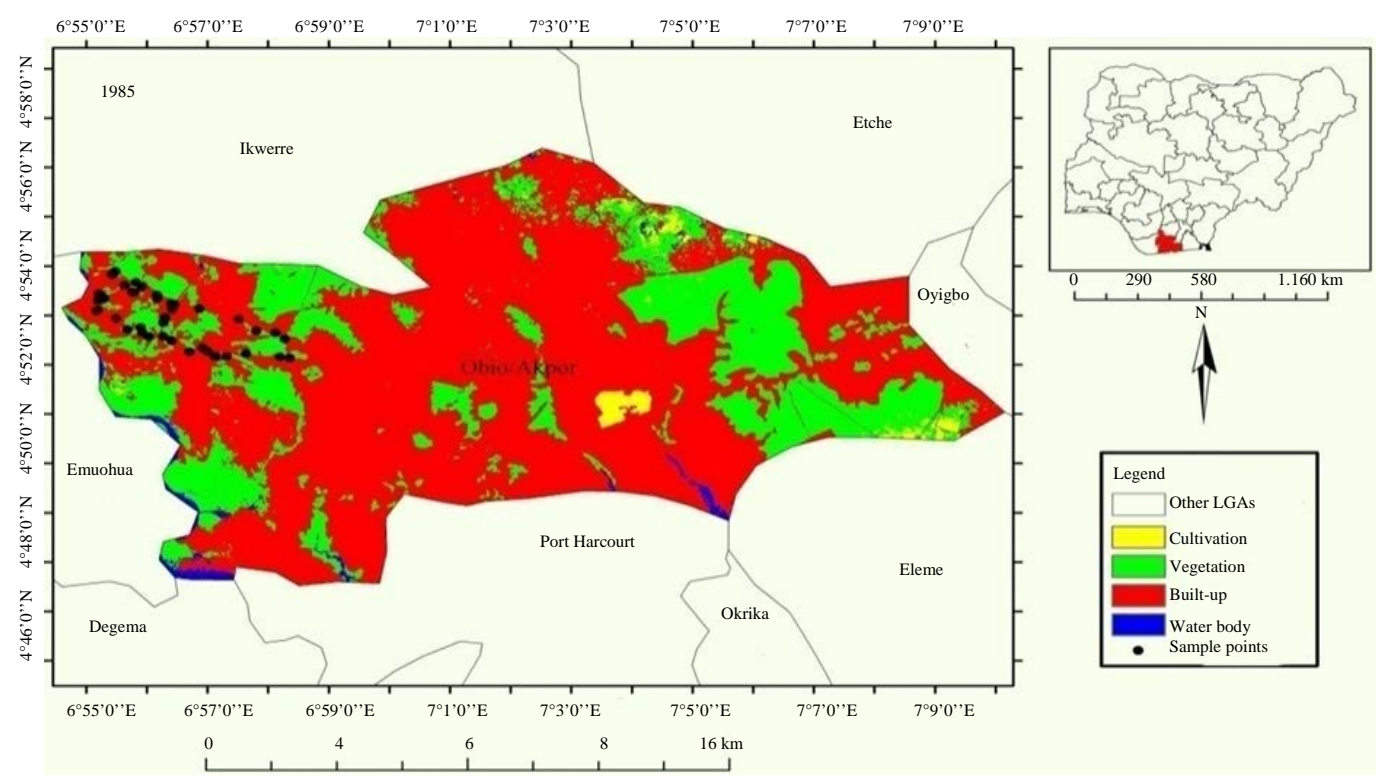

Fig. 6: Map showing the land use in the study area in 2017 (Department of Geography and Environmental Management, University of Port Harcourt, Choba)

importation of some agricultural produce by the government and a decline in vegetation. In both years, the water body remained the same. Distribution of landuse and landcover between 1985 and 2017 are showed in Fig. 5 and 6.

\section{CONCLUSION}

This research has examined the implications of land use on vegetative land cover using remote sensing and GIS in communities in Obio/Akpor LGA, it revealed that there was substantial land use changes in the area between the 1985 and 2017 reference years. The most important changes were the conversion of vegetation to built-up areas and cultivation lands; water body resources remained constant, decline in vegetation, cultivation and built-up areas showed increment. Moreover, the expansion of cultivation and built-up settlements and the decrease in vegetation lands occurred because of population pressure which was caused by people flooding the study area for white collar jobs. The implication drawn from this research work shows that vegetative landcover of the study area was greatly influenced by land use and land cover types/change.

\section{REFERENCES}

Adeniyi, P.O and A. Omojala, 1999. Land Use and Land Cover Change Evaluation in Sokoto-Rima Basin of North Western Nigeria Based on Archival Remote Sensing and GIS Techniques. In: Geoinformation Technology Applications for Resource and Environmental Management in Africa, Adeniyi, P.O. (Ed.). Wura-Kay Prints, Lagos, pp: 120-129.

Ayad, Y.M., 2005. Remote sensing and GIS in modeling visual landscape change: A case study of the North Western arid coast of Egypt. Landscape Urban Plann., 73: 307-325.

Ejemeyovwi, D.O., 2015. Change detection in land use/land cover mapping in Asaba, Niger delta between 1996 and 2015. A remote sensing and GIS approach. Br. J. Environ. Sci., 3: 42-61.

Ruiz-Luna, A. and C.A. Berlanga-Robles, 2003. Land use, land cover changes and coastal lagoon surface reduction associated with urban growth in northwest Mexico. Landscape Ecol., 18: 159-171.

Turner, M.G. and C.L. Ruscher, 1988. Changes in landscape patterns in Georgia, USA. Landscape Ecol., 1: 241-251. 